Ekonomia - Wroclaw Economic Review 27/2 (2021)

Acta Universitatis Wratislaviensis

No 4067

https://doi.org/10.19195/2658-1310.27.2.3

Mahmut Zeki Akarsu

ORCID: 0000-0002-8140-4124

University of Warsaw

m.akarsu@uw.edu.pl

\title{
Investigating the causal relationship between economic growth, inflation, and unemployment in South Korea
}

Date of submission: 12.06 .2021 , date of acceptance: 28.08 .2021

JEL classification: E10, E24, O47, O53

Keywords: South Korea, economic growth, inflation, unemployment, VAR model

\begin{abstract}
Investigating causal relationship between economic growth, inflation, and unemployment in South Korea

Policymakers and economists consistently implement monetary and fiscal policy to control economic growth, inflation, and unemployment due to the fact that these three factors directly influence people's living standards. Every country has a different economic characteristic structure. Economic growth and inflation have a strong correlation in some countries, while other countries have a strong correlation between economic growth and unemployment. Therefore, investigating the causal relationship among economic factors can provide us with a better understanding of how economic phenomena affect each other. In South Korea, economic growth, inflation, unemployment have been in balance since the 1998 Korean economic crisis. Hence, investigating the economic growth, inflation, and unemployment of South Korea will enlighten how these three economic indicators affect each other in a country that developed rapidly and had several economic crises. To investigate such a model, the Vector Autoregressive Model (VAR) is used with the data between the years 1980 and 2019 in order to verify whether Okun's law or/and the Philips curve hold in South Korea. The research also determines if there is either a bi-directional or uni-directional relationship if economic growth, inflation, and unemployment have a causal relationship. The research demonstrates that GDP is the main factor in South Korea that influences the other economic factors. This research paper can contribute to academia, since it has a vital outcome which shows that the mobility of the unemployment rate in South Korea is directly correlated to the movement of GDP.
\end{abstract}

Ekonomia - Wroclaw Economic Review 27/2 (2021)

(C) for this edition by CNS 


\section{Introduction}

GDP, inflation, and unemployment are at the core of the goals of macroeconomic policies. The sharp or smooth change of these three economic factors directly influences societies and might cause social and economic problems. For instance, If economic growth persists at too rapid a rate, inflation might accelerate, or if economic growth is lagging, then unemployment may increase. Namely, economic growth, inflation, and unemployment significantly impact economic development. Therefore, governments and policymakers examine GDP, inflation, and unemployment. (Cashell, 2006; Tenzin, 2019).

Braumann (2000) found that high inflation harms the real economy. High inflation causes a sharp decline in real money holdings, a decline in output, private consumption, and real wages. On the other hand, Rogoff (2003) remarked that deflation triggered falling prices, output, profits, and employment. Overall, both high inflation and deflation hurt the countries' economies.

Powell (1973) indicated that unemployment affects people's living standards at the moment and in the future. Unemployment also causes the children of unemployed families not to have enough education opportunities. Some of the children drop out of school primarily to work. Another impact of chronic unemployment is that educated and well-trained workers lose skills as the period of unemployment grows longer.

Low economic growth (e.g., Yemen and Venezuela) (Worldbank, 2020) can lead to social and economic problems. In the OECD report, Department for International Development noted that economic growth (mostly high growth) reduces poverty, improves life quality, creates jobs, and drives human development (Great Britain DFID, 2008).

With the importance of these factors, scholars have researched how these macroeconomic indicators are interrelated. William Phillips was one of the scholars investigating those three core macroeconomic factors to understand the causal relationship. He asserted that unemployment and inflation have an inverse relationship. When the unemployment level is low, inflation will rise due to a worker's spendings. When the unemployment level is high, inflation will drop due to the lack of spending (Clark \& Douglas, 1997). However, since Phillips made this claim, many scholars have analyzed it in various countries and found that the Phillips curve is not valid for every country.

Arthur Melvin Okun is also another scholar who delved into economic growth and unemployment. He claimed that economic growth and unemployment have a negative relationship. Similar to the Phillips curve, empirical studies show that Okun's law has held in some countries, but not in all of them (Prachowny, 1993). Therefore, empirical research to analyze a causal relationship between economic growth, inflation, and unemployment is significant for future economic development.

Ekonomia - Wroclaw Economic Review 27/2 (2021)

(C) for this edition by CNS 
For many decades, as mentioned above, academics, policymakers, and economists have tried to find how macroeconomic instruments affect each other. In this tradition, checking South Korean economic indicators' relationship remains essential because South Korea is one of the miraculous economies that developed rapidly and joined the developed country's club from the underdeveloped country's league within 30 years. However, in the development path, South Korea had economic recessions in its history in 1968, 1974, 1979, and 1991. In 1998, the economic crisis in Southeast Asia crushed South Korea's economy, and the inflation rate went up to $7.5 \%$ from $4.4 \%$, as the unemployment rate rose to $7 \%$ in 1998 , up from $2.6 \%$ in 1997. Besides, the economic growth rate shrank to $-5.1 \%$ in 1998 (Park, 2005). Therefore, this research may provide us with a better understanding of how macroeconomic factors work in such a country which developed quickly while experiencing severe economic crises.

In this study, the nexus between GDP, inflation, and unemployment is analyzed from 1980 to 2019 in South Korea to check whether Okun's law and the Phillips curve theory apply to the South Korean economy or not, using Phillips-Perron unit root testing, Johansen cointegration testing, vector autoregression model (VAR), and Granger causality testing.

\section{Literature review}

Fisher (1993), Cetintas (2003), and Gillman, Harris, Matyas (2004) studied the relationship between economic growth and inflation, and found out that inflation negatively affects economic growth. Barro (1995) researched inflation and economic growth in around 100 countries during the period between 1960-1990 and inferred from the empirical result that the effects of inflation on economic growth and investment are significantly negative. Andres and Hernando (1997) studied the nexus between inflation and economic growth in OECD countries during the 1960-1992 period. The research did not find a relationship between inflation and the GDP growth rate, yet it found a statistically significant negative relationship between inflation and GDP per capita level. Mubarik (2005) alleged that the above $9 \%$ threshold value shows a negative relationship between inflation and economic growth, yet the below 9\% is no causal relationship in Pakistan. Vaona and Schiavo (2007) observed the long-run relationship between inflation and economic growth using 167 countries between the years 1960 and 1999.

Hsing (1989) worked on the data of six industrialized nations from 1964 to 1986, and the empirical result demonstrated an inverse relationship between inflation and unemployment in the U.S., Canada, Italy, Japan, the U.K., and West Germany. Skare and Caporale (2014) explained that their empirical research showed that in the short-run, the inflation Granger causes employment positively, yet in the long-run inflation-employment relations become negative. Ortansa (2014) exam-

Ekonomia - Wroclaw Economic Review 27/2 (2021)

(C) for this edition by CNS 
ined the nexus between inflation and youth unemployment in Romania and found that the Phillips Curve exists in Romania. Al-zeaud (2014) alleged that the research could not show a causal relationship between inflation and unemployment in Jordan. N'Guessan (2018) remarked that in the long-run, unemployment growth causes the increasing price level; namely, the relationship between inflation and unemployment exists, and it is positive.

Kreishan (2011) proposed that economic growth and unemployment are unrelated in Jordan. Therefore, he clarified that Okun's law is not observed in Jordan. AlWadi and Khrais (2016) conducted scientific research about economic growth and unemployment relationship in MENA countries between the years 1990-2016, and the result was that there is an insignificant relationship between unemployment and economic growth in MENA countries. Soylu, Cakmak, Okur (2018) researched the nexus between unemployment and economic growth in Eastern European Countries between the years 1992-2014, and the result is that unemployment and economic growth are related to each other. Dayioglu and Aydin (2020) found that economic growth and unemployment are strongly correlated in Turkey.

Özdemir, Mercan, Erol (2012) studied the nexus between inflation, economic growth, unemployment, and minimum wage, and the result showed that in the long run, an increase in the minimum wage and inflation induces an increase in unemployment, but an increase in economic growth decreases unemployment. Senturk and Akbas (2014) asserted that there is a strong correlation between the industrial production index, inflation, and unemployment. Mohseni and Jouzaryan (2016) investigated the effect of inflation and unemployment on economic growth in Iran during the 1996-2012 period, and they discovered that inflation and unemployment have a significant impact on economic growth in Iran.

Table 1. Literature review of the relationship between inflation and unemployment

\begin{tabular}{|l|l|c|c|c|}
\hline \multicolumn{1}{|c|}{ Author } & \multicolumn{1}{|c|}{ Sample } & Period & Methodology & Result \\
\hline Furuoka (2007) & Malaysia & $1973-2004$ & VECM & INF $\rightarrow$ UE \\
\hline Furuoka (2008) & Philippines & $1980-2006$ & VECM & $\times$ \\
\hline $\begin{array}{l}\text { Kogid, Asid, Mulok, Lily, } \\
\text { Loganathan (2011) }\end{array}$ & Malaysia & $1975-2007$ & ARDL & INF $\rightarrow$ UE \\
\hline $\begin{array}{l}\text { Zaman, Khan, Ahmad, } \\
\text { Ikram (2011) }\end{array}$ & Pakistan & $1975-2009$ & VECM & INF $\rightarrow$ UE \\
\hline $\begin{array}{l}\text { Umaru and Zubairu } \\
\text { (2012) }\end{array}$ & Nigeria & $1984-1997$ & OLS & $\times$ \\
\hline $\begin{array}{l}\text { Ul-Haq, Khan, Khan, } \\
\text { Ahmed (2012) }\end{array}$ & Pakistan & $1974-2010$ & VECM & INF $\rightarrow$ UE \\
\hline $\begin{array}{l}\text { Mahmood, Bokhari, } \\
\text { Aslam (2013) }\end{array}$ & Pakistan & $1992-2011$ & $\begin{array}{l}\text { VECM, } \\
\text { FEVD }\end{array}$ & INF $\rightarrow$ UE \\
\hline Touny (2013) & Egypt & $1974-2011$ & VECM & UE $\rightarrow$ INF (positively) \\
\hline
\end{tabular}

Ekonomia - Wroclaw Economic Review 27/2 (2021)

(C) for this edition by CNS 


\begin{tabular}{|l|l|c|c|c|}
\hline Cioran (2014) & $\begin{array}{l}\text { Romania } \\
\text { and the EU }\end{array}$ & 1997-2013 & $\begin{array}{c}\text { regression } \\
\text { model }\end{array}$ & INF $\rightarrow$ UE (negatively) \\
\hline Israel (2015) & $\begin{array}{l}\text { France, } \\
\text { Germany, } \\
\text { the UK, } \\
\text { the US }\end{array}$ & $1956-2004$ & ARDL & INF $\leftrightarrow$ UE \\
\hline $\begin{array}{l}\text { Okafor, Chijindu, Ugo- } \\
\text { chukwu (2016) }\end{array}$ & Nigeria & $1989-2014$ & ECM & INF $\rightarrow$ UE (negatively) \\
\hline Ştefan and Bratu (2016) & the US & $1961-2013$ & VAR & INF $\rightarrow$ UE \\
\hline
\end{tabular}

Note: INF: inflation; UE: unemployment

$\rightarrow$ : unidirectional relation; $\leftrightarrow$ : bidirectional relation; $\times$ : no relation

Table 2. Literature review of the relationship between GDP and unemployment

\begin{tabular}{|c|c|c|c|c|}
\hline Author & Sample & Period & Methodology & Result \\
\hline $\begin{array}{l}\text { Aghion and Howitt } \\
\text { (1992) }\end{array}$ & OECD countries & 1974-1989 & $\begin{array}{l}\text { cointegration } \\
\text { analysis }\end{array}$ & $\begin{array}{l}\mathrm{GDP} \rightarrow \mathrm{UE} \\
\text { (negatively) }\end{array}$ \\
\hline $\begin{array}{l}\text { Baretto and Howland } \\
\text { (1993) }\end{array}$ & Japan & 1953-1982 & $\begin{array}{l}\text { regression } \\
\text { estimation }\end{array}$ & $x$ \\
\hline $\begin{array}{l}\text { Marinkov and } \\
\text { Geldenhuys (2007) }\end{array}$ & South Africa & 1970-2005 & ECM and VECM & $\mathrm{GDP} \leftrightarrow \mathrm{UE}$ \\
\hline Lin and Huang (2008) & the US & 1948-2006 & $\begin{array}{c}\text { smooth-time- } \\
\text { varying-parameter }\end{array}$ & $\mathrm{GDP} \leftrightarrow \mathrm{UE}$ \\
\hline $\begin{array}{l}\text { Ceylan and Sahin } \\
\text { (2010) }\end{array}$ & Turkey & 1950-2007 & TAR and M-TAR & $\begin{array}{c}\text { GDP } \leftrightarrow \text { UE (in } \\
\text { the long run) }\end{array}$ \\
\hline Akram et al. (2014) & Pakistan & 1972-2012 & OLS & $x$ \\
\hline $\begin{array}{l}\text { Lozanoska and } \\
\text { Dzambaska (2014) }\end{array}$ & Macedonian & 2005-2012 & OLS & $x$ \\
\hline Phiri (2014) & South Africa & 2000-2013 & MTAR & $\mathrm{GDP} \leftrightarrow \mathrm{UE}$ \\
\hline Ruxandra (2015) & Romania & 2007-2013 & ANOVA & $\mathrm{GDP} \leftrightarrow \mathrm{UE}$ \\
\hline Makun and Azu (2015) & Fiji & 1982-2012 & $\mathrm{ECM}$ & $\begin{array}{c}\text { GDP } \leftrightarrow \text { UE (in } \\
\text { the long run) }\end{array}$ \\
\hline
\end{tabular}

Note: UE: unemployment; GDP: Gross Domestic Product;

$\rightarrow$ : unidirectional relation; $\leftrightarrow$ : bidirectional relation; $\times$ : no relation

Table 3. Literature review of relationship between GDP and inflation

\begin{tabular}{|l|l|c|c|c|}
\hline \multicolumn{1}{|c|}{ Author } & \multicolumn{1}{|c|}{ Sample } & \multicolumn{1}{c|}{ Period } & Methodology & \multicolumn{1}{c|}{ Result } \\
\hline Barro (1996) & $\begin{array}{l}100 \text { coun- } \\
\text { tries }\end{array}$ & $1960-1990$ & $\begin{array}{c}\text { regression } \\
\text { equation }\end{array}$ & GDP $\leftrightarrow$ INF (negatively) \\
\hline Nell (2000) & South Africa & $1960-1990$ & VAR & GDP $\leftrightarrow$ INF (negatively) \\
\hline $\begin{array}{l}\text { Erbaykal and Okuyan } \\
(2008)\end{array}$ & Turkey & $1987-2006$ & ARDL & GDP $\leftrightarrow$ INF (negatively) \\
\hline
\end{tabular}




\begin{tabular}{|l|l|c|c|c|}
\hline Munir (2009) & Malaysia & $1970-2005$ & TAR & GDP $\leftrightarrow$ INF (negatively) \\
\hline $\begin{array}{l}\text { Datta and Mukho- } \\
\text { padhyay (2011) }\end{array}$ & Malaysia & $1971-2007$ & $\begin{array}{c}\text { Granger } \\
\text { causality }\end{array}$ & $\times$ \\
\hline Kigume (2011) & Kenya & $1963-2000$ & $\begin{array}{c}\text { Granger } \\
\text { causality }\end{array}$ & $\times$ \\
\hline $\begin{array}{l}\text { Sa'idu and } \\
\text { Muhammad (2015) }\end{array}$ & Nigeria & $1986-2010$ & $\begin{array}{c}\text { Granger } \\
\text { causality }\end{array}$ & GDP $\rightarrow$ INF \\
\hline
\end{tabular}

Note: INF: inflation; GDP: gross domestic product

$\rightarrow$ : unidirectional relation; $\leftrightarrow$ : bidirectional relation; $\times$ : no relation

\section{Empirical analysis}

The South Korean consumer price index, unemployment, and real gross domestic product will be examined in terms of the causal relationship using econometric time-series models, the augmented Phillips-Perron unit root test, Johansen cointegration test (Intercept [no trend] in CE), and VAR model.

\subsection{Data and methodology}

The research has identified the influential variables to analyze unemployment, real gross domestic product, and consumer price index $(2015=100)$ in South Korea during the 1980-2019 period. The data is taken from the World Bank. In the study, the real gross domestic product represents GDP, and consumer price index represents inflation, and the unemployment rate represents unemployment. In the research, the annual data set is analyzed.

\subsection{Unit root test}

As can be seen in Figure 1, in 1998, consumer price and unemployment rose sharply, while the GDP declined due to the 1998 Korean economic crisis (called the IMF crisis). However, except for the 1998 crisis, the consumer price and GDP of South Korea have steadily increased, and unemployment has remained around $3.5 \%$. This empirical study specifies whether the variables are stationary or non-stationary. The Phillips-Perron unit root test is used for this empirical study.

Firstly, $\mathrm{I}(0)^{1}$ in intercept, the intercept-trend test is applied for real GDP, consumer price index, and unemployment. GDP and consumer price index were non-stationary (has unit-roots) in both intercept and trend-intercept tests. However, unemployment was non-stationary in the trend and intercept test, even if it

\footnotetext{
1 Unit root test in level.
}

Ekonomia - Wroclaw Economic Review 27/2 (2021)

(C) for this edition by CNS 


\section{Gross Domestic Product (GDP)}

$2.0 \mathrm{E}+12$

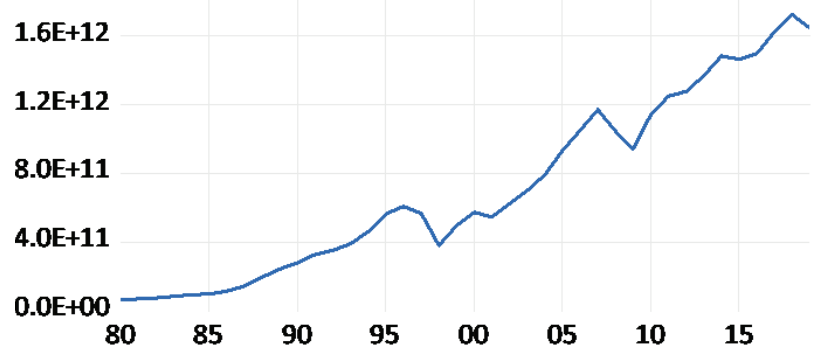

Consumer price index

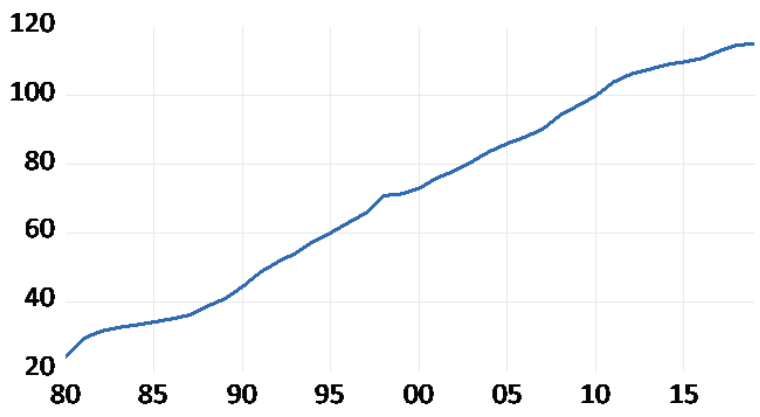

\section{Unemployment}

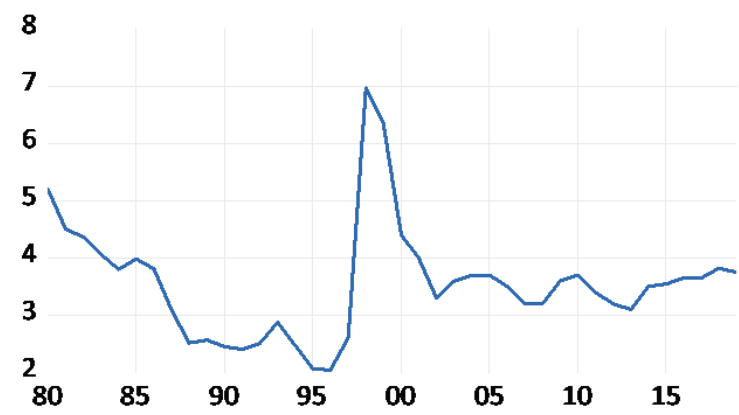

Figure 1. The graph of GDP, unemployment, and consumer price between 1980 and 2019 Source: Author.

was stationary in the intercept test. Therefore, unemployment is considered as a non-stationary series. Subsequently, the first difference $\left(\mathrm{I}(1)^{2}\right)$ test is performed for all three non-stationary variables. Three variables became stationary after the first difference in the Phillips-Perron unit root (see Table 1A in Appendix).

\footnotetext{
${ }^{2}$ Unit root test in first difference.
}

Ekonomia - Wroclaw Economic Review 27/2 (2021)

(C) for this edition by CNS 


\subsection{Cointegration analysis}

Three variables are non-stationary and become stationary after taking the first difference using the Phillips-Perron unit root test. That fulfills the conditions of the cointegration test, which is used to prevent spurious regression. Therefore, this empirical study uses the Johansen cointegration test to find whether variables have long-run relationships. Firstly, the six lag lengths are analyzed, which is necessary to test Johansen cointegration. The result of the lag length is viewed in Table 2A (Appendix).

To determine the best-fit lag length, all six lags are observed by using selection criteria. LR, FPE, AIC, and HQ pointed out that the second lag is the best fit for the model.

After specifying the lag length, the Johansen cointegration test is applied to determine whether variables take joint actions in the long-run, using Intercept (no trend) in CE and test VAR.

Table 4AB. Result of Johansen cointegration test. Null hypothesis: there is no cointegration between GDP, inflation, and unemployment

\begin{tabular}{|l|c|c|c|c|}
\hline \multicolumn{5}{|c|}{ Unrestricted cointegration rank test (trace) } \\
\hline $\begin{array}{c}\text { Hypothesized } \\
\text { no of CE(s) }\end{array}$ & Eigenvalue & Trace statistic & $\begin{array}{c}0.05 \\
\text { Critical value }\end{array}$ & Prob.** \\
\hline None* & 0.498573 & 38.62826 & 29.79707 & 0.0037 \\
\hline At most 1 & 0.244964 & 12.39696 & 15.49471 & 0.1389 \\
\hline At most 2 & 0.044238 & 1.719366 & 3.841465 & 0.1898 \\
\hline
\end{tabular}

Note: Trace test indicates 1 cointegrating eqn (s) at the 0.05 level

$*$ denotes rejection of the hypothesis at the 0.05 level

** MacKinnon-Haug-Michelis (1999) p-values

\begin{tabular}{|l|c|c|c|c|}
\hline \multicolumn{5}{|c|}{ Unrestricted cointegration rank test (trace) } \\
\hline $\begin{array}{c}\text { Hypothesized } \\
\text { no of CE(s) }\end{array}$ & Eigenvalue & $\begin{array}{c}\text { Max-Eigen } \\
\text { statistic }\end{array}$ & $\begin{array}{c}0.05 \\
\text { Critical value }\end{array}$ & Prob.** \\
\hline None* & 0.498573 & 26.23129 & 21.13162 & 0.0088 \\
\hline At most 1 & 0.244964 & 10.67760 & 14.26460 & 0.1711 \\
\hline At most 2 & 0.044238 & 1.719366 & 3.841465 & 0.1898 \\
\hline
\end{tabular}

Note: Max-eigenvalue test indicates 1 cointegrating eqn (s) at the 0.05 level

* denotes rejection of the hypothesis at the 0.05 level

** MacKinnon-Haug-Michelis (1999) p-values

Source: Author.

According to Table 4, trace and maximum eigenvalue statistics have one cointegrating equation, which means that our variables are cointegrated, and the long-run relationship exists among variables. 
In an econometric analysis, to stabilize non-stationary variables, it is necessary to take the first or second differences of variables. However, taking first or second difference of series might cause to lose the long-run relation among series. Therefore, even if the series are non-stationary, it could be assumed that the series might have a stable linear combination, and to specify that econometrically, a cointegration test is used. If non-stationary variables have cointegrations, then those variables are cointegrated, and the levels of series, which are statistically significant, are not spurious regressions (Tari, 2014, 405).

\subsection{Result of VAR analysis}

There is a lot of discussion about whether the VAR model should be stationary or not because data is lost by taking first or second difference of series. Sims (1980), and Cooley \& LeRoy (1985) claimed that the aim of applying VAR analysis is to estimate the relationship among variables rather than parameter estimation.

In accordance with Sims (1980) as well as Cooley and LeRoy (1985), in this empirical research, variables are used without taking the first difference. The VAR model is analyzed from the point of stabilization.

The Inverse Root of AR Characteristic Polynomial shows that AR roots are between -1 and +1 . It proves that the VAR model is stabilized, and any shock will die out in the long-run.

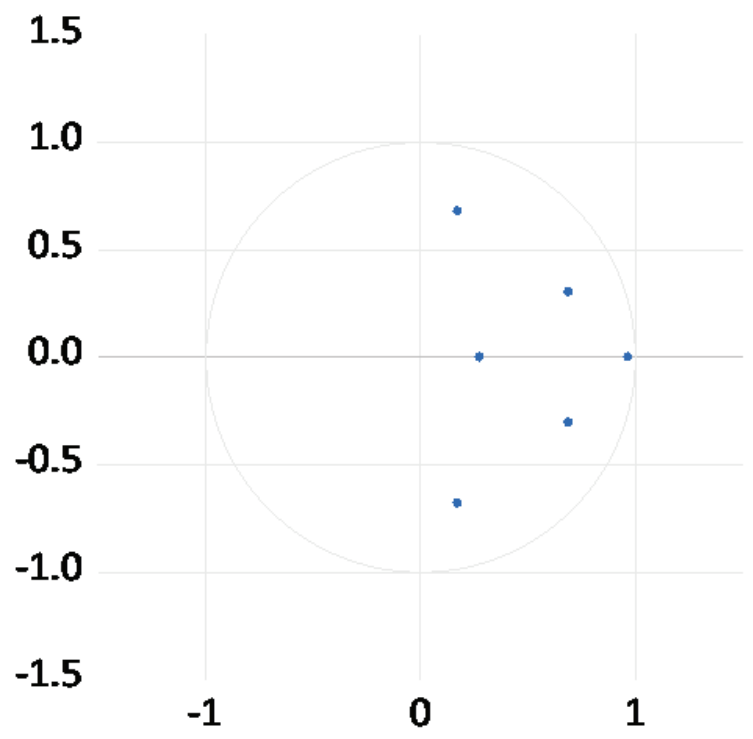

Figure 2. The result of inverse roots of AR characteristic polynomial Source: Author.

Ekonomia - Wroclaw Economic Review 27/2 (2021)

(C) for this edition by CNS 


\subsection{Impulse response function (IRF)}

The impulse response function is to indicate that the response of variables (endogenous variables) to the shock that happens in other endogenous variables in a dynamic VAR system. The IRF is used to analyze the effect of one standard deviation of the shock from one innovation variable on current or future endogenous variables (Amri, Nazamuddin, 2018). In the study, innovation variables are GDP, inflation, and unemployment.

LNGDP denotes logarithmic real GDP, LNINF denotes logarithmic Consumer Price Index, and UNEMP denotes unemployment. Before the model is implemented, the logarithm was taken for real GDP and Consumer Price Index to have a result in percentage, but unemployment data does not need logarithmic transformation since it is collected in percentage.

The response of LNGDP indicates how GDP responds to the standard deviation shock of variables. GDP responds positively to the shock of inflation by one standard deviation (LNINF) during the given period of time. However, GDP responds positively to the shock of unemployment (UNEMP) in the first third period by 1 standard deviation. After that, GDP responds negatively to the shock of unemployment. Furthermore, GDP responds positively to the shock of GDP by 1 standard deviation.

The response of LNINF result shows that inflation responds negatively to the shock of unemployment by one standard deviation in the second, seventh, eighth, ninth, and tenth periods; in other periods, responses of inflation is positive to the shock of unemployment. inflation responds mostly positively to the shock of GDP by one standard deviation in every period except the first period. Finally, the response of inflation to the shock of inflation is positive by one standard deviation in every given period.

Unemployment responds negatively to the shock of GDP in the first period. Subsequently, the response of UNEMP indicates that unemployment responds positively to the one standard deviation shock of GDP during the other given periods. Unemployment responds positively to the shock of inflation in all periods. Unemployment responds positively to the shock of unemployment except for the period of second, seventh, eighth, ninth, tenth when unemployment's response is negative to the shock.

\subsection{Variance decomposition analysis (VCD)}

Variance decomposition determines how much variability in the dependent variable is lagged by its variance and other variables' variances. Additionally, it explains which of the independent variables is more robust in explaining the dependent variables' variability over time. In VCD, the order of the variables is of paramount

Ekonomia - Wroclaw Economic Review 27/2 (2021)

(C) for this edition by CNS 
importance. The order should be from exogenous to endogenous (Tari, Koc, Abasiz, 2019, 485).

Variance decomposition of LNGDP illustrates that GDP in the first period can explain its own variance by $100 \%$. However, in the 10 th period, inflation and unemployment can explain the variance of GDP by $8.74 \%$ and $4.59 \%$, respectively, while the GDP can explain its own variance by $86.68 \%$. In other words, unemployment and inflation are the causes of the variance of the GDP.

As shown in variance decomposition of LNINF, in the first period, inflation accounts for $99.65 \%$ variation of its own variance, as GDP explains about $0.35 \%$ of inflation variation in the short-run. However, GDP is able to account for more and more in the process of periods, and in the 10th period, GDP accounts for $73.15 \%$ of inflation variation in the long-run, while inflation can explain $25.98 \%$ of its variation. Therefore, it can be said that there is a relationship between GDP and inflation, and GDP has a significant impact on inflation.

It has been observed from the result of variance decomposition of UNEMP that from the first period to the 10th period, GDP (LNGDP) has a significant effect on unemployment in both the short and long-run. GDP explains roughly $76.67 \%$ of unemployment variation in the given periods, as unemployment accounts for approximately $29.07 \%$ in the first period and $18.86 \%$ in the 10 th period of its variation. In addition, inflation (LNINF) explains $7.15 \%$ of unemployment variation in the first period and explains $4.47 \%$ of unemployment variation in the 10 th. Hence,



Figure 3. Impulse response graphs among variables

Source: Author.

Ekonomia - Wroclaw Economic Review 27/2 (2021)

(C) for this edition by CNS 




Figure 4. Graphs of variance decomposition

Source: Author.

it can be predicted that inflation also has a little bit of impact on unemployment, but the effect of inflation on unemployment decreases over the period.

In short, GDP can significantly account for the variation of inflation and unemployment. unemployment and inflation cannot explain the variation of each other and GDP as significantly as GDP does.

\subsection{Granger causality test}

The Granger causality test is used to find a causal relationship among variables. In the Granger causality test, endogenous variables are treated as exogenous.

If the probability value in Granger causality is higher than 0.05 , then " $\mathrm{H} 0$ : Granger does not Granger cause" cannot be rejected. However, if the probability value is not higher than 0.05 , the null hypothesis is rejected and said that it is statistically significant, which means a uni-directional causal relationship between variables.

According to Table 5, the result revealed a uni-directional causality running from GDP (LNGDP) to inflation (LNINF) as measured by the consumer price index. That means that GDP Granger causes inflation.

Unemployment and GDP have a bi-directional relationship. It means that unemployment (Unemp) Granger causes GDP, while GDP Granger causes unemployment.

Ekonomia - Wroclaw Economic Review 27/2 (2021)

(C) for this edition by CNS 
Table 5. The result of the Granger causality test

\begin{tabular}{|l|c|c|c|c|}
\hline \multicolumn{5}{|c|}{$\begin{array}{c}\text { VAR Granger causality/block exogeneity Wald tests } \\
\text { Included observations: } 38\end{array}$} \\
\hline Dependent variable: LNGDP & df & Prob. & \\
\hline Excluded & Chi-sq & 2 & 0.2568 & \\
\hline LNINF & 2.718780 & 2 & $\mathbf{0 . 0 1 2 0}$ & P $<\mathbf{0 . 0 5}$ \\
\hline UNEMP & 8.838180 & 4 & $\mathbf{0 . 0 2 0 8}$ & P $<\mathbf{0 . 0 5}$ \\
\hline All & 11.58053 & & Prob. & \\
\hline Dependent variable: LNINF & Chi-sq & df & $\mathbf{0 . 0 1 0 1}$ & P $<\mathbf{0 . 0 5}$ \\
\hline Excluded & 9.199977 & 2 & 0.7081 & \\
\hline LNGDP & 0.690348 & 2 & $\mathbf{0 . 0 0 0 0}$ & P $<\mathbf{0 . 0 1}$ \\
\hline UNEMP & 31.58383 & 4 & & \\
\hline All & Chi-sq & df & Prob. & \\
\hline Dependent variable: UNEMP & 2 & $\mathbf{0 . 0 4 5 2}$ & P $<\mathbf{0 . 0 5}$ \\
\hline Excluded & 6.193881 & 2 & 0.9975 & \\
\hline LNGDP & 0.004934 & 4 & 0.1608 & \\
\hline LNINF & 6.564654 & & & \\
\hline All & & 2 & & \\
\hline
\end{tabular}

Note: Null hypothesis: independent variable does not Granger cause dependent variable Source: Author.

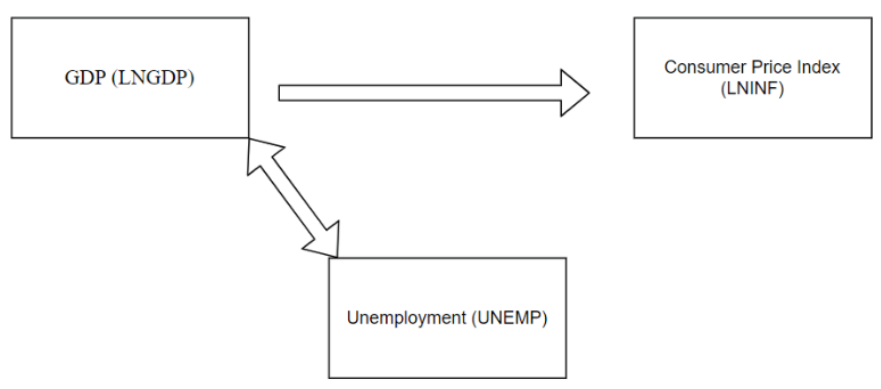

Figure 5. The direction of VAR Granger causality/Block exogencity Wald tests Source: Author.

\section{Research findings and discussion}

Many scholars and articles indicate that inflation and unemployment have a vital relationship in many different countries. For instance, Ştefan and Bratu (2016), Okafor et al. (2016), and Israel (2015) state that inflation plays a vital role in the 
economy and impacts unemployment in many different developed countries. In South Korea, inflation does not have an impact on unemployment, and vice versa. Firstly, this might be because South Korea's population density is on the decline. Secondly, in South Korea, part-time jobs are pretty popular amongst workers (mainly amongst young workers), and unemployed people have part-time jobs until they find decent jobs. Finally, the density of the young population has been decreasing; therefore, youth unemployment does not significantly influence the total unemployment rate (Lee, 2017, 1, 7, 8).

In Korea, as has been found in other articles, inflation and economic growth have a uni-directional relationship from GDP to inflation. When GDP increases, inflation also goes up, and vice versa. It is because when GDP grows in South Korea, people's income accelerates. With more income, Koreans tend to spend more because South Korea is a consumer society (UKEssays, 2018).

GDP and unemployment have a strong correlation in South Korea. GDP predominantly directs unemployment, as is seen in the result of VCD (Figure 4). In South Korea's economy, GDP is the main economic driving factor influencing some economic factors flat-out, such as inflation and unemployment. The Korean government should balance between unemployment and inflation, because low economic growth might trigger joblessness, yet high economic growth might cause relatively high inflation. Thus, investigating and monitoring the main economic factors is of paramount importance in South Korea.

\section{Conclusion}

In the study, the causal relationship between unemployment, inflation, and economic growth was analyzed using the South Korean real gross domestic product data, South Korean consumer price index data, and South Korean unemployment rate data between the years 1980 and 2019.

The result of the VAR model demonstrated that GDP affects inflation, but there is no reverse relationship. In the variance decomposition, it is clearly seen that GDP has an enormous impact on inflation; when the GDP increases or decreases, inflation follows the path of GDP and increases or decreases in the standard economic conditions. During economic recessions, GDP decreases, while inflation rises in South Korea.

There is an incredibly significant nexus between unemployment and GDP. Figure 4 illustrates that to understand and notice the change in unemployment, we have to analyze the GDP, because without the GDP, unemployment cannot be readily explained in South Korea, which means that the movement of unemployment is steered by the GDP.

The nexus between unemployment and GDP is powerful. In future research, threshold regression analysis could be used to determine whether the economic

Ekonomia - Wroclaw Economic Review 27/2 (2021)

(C) for this edition by CNS 
growth threshold level has a positive or negative effect on unemployment. That sort of analysis would be worthwhile due to the fact that the economic growth of South Korea has been diminished by the effect of the iron logic of diminishing returns.

To sum up, for many years, economists, policymakers, and economic agents have tried to solve the riddle of inflation and unemployment. Those two factors always influence people's life and living standards in no time, and those two economic phenomena are a strong relationship with economic growth. Hence, economic agents and policymakers need to monitor South Korea's economic growth closely in order to shun the overheated economy and maintain sustainable economic growth. Because South Korea's economic growth directly impacts inflation and unemployment, overheated economic growth might disturb the balance of these indicators. Otherwise, the reinless economy could be overheated, and overheating economy may cause many issues in South Korea.

\section{References}

Aghion, P., Howitt, P. (1992). A model of growth through creative destruction. Econometrica, 60 (2), 323-351. Retrieved from http://www.jstor.org/stable/2951599.

Al-Wadi, M., Khrais, I. (2016). Economic growth and unemployment relationship: An empirical study for MENA countries. International Journal of Managerial Studies and Research, 4 (12), 19-24.

Al-zeaud, H. (2014). The trade off between unemployment and inflation evidence from causality test for Jordan. International Journal of Humanities and Social Science, 4, 103-111.

Amri, K., Nazamuddin, B.S. (2018). Is there causality relationship between economic growth and income inequality?: Panel data evidence from Indonesia. Eurasian Journal Of Economics And Finance, 6 (2), 8-20.

Andres, J., Hernando, I. (1997). Inflation and economic growth: Some evindence for the OECD countries. In M. Feldstein (ed.), The Costs and Benefits of Achieving Price Stability (364385). New York: NBER.

Barreto, H., Howland, F. (1993). There Are Two Okun's Law Relationships Between Output and Unemployment. Crawfordsville: Wabash College.

Barro, R.J. (1995). Inflation and economic growth. NBER Working Paper Series, 5326.

Barro, R.J. (1996). Determinants of economic growth: A cross-country empirical study. NBER Working Paper Series, 5698. DOI:10.3386/w5698

Braumann, B. (2000). Real effects of high inflation. International Monetary Fund, Working Paper, 85.

Cashell, B. (2006). Economic Growth, Inflation and Unemployment Limits to Economic Policy. Washington D.C.: CRS Report for Congress.

Çetintaş, H. (2003). Türkiye'de Enflasyon ve Büyüme [Inflation and economic growth in Turkey]. Istanbul University Journal of Political Science, 28, 141-153.

Ceylan, S., Sahin, B.Y. (2010). Asymmetry in the relationship between unemployment and economic growth. Dogus University Journal, 11 (2), 157-165. Retrieved from http://journal.dogus. edu.tr/index.php/duj/article/view/15.

Cioran, Z. (2014). Monetary policy, inflation and the causal relation between the inflation rate and some of the macroeconomic variables. Procedia Economics and Finance, 16, 391-401. Retrieved from https://www.sciencedirect.com/science/article/pii/S2212567114008181?via\%3Dihub. 
Clark, P., Douglas, L. (1997). Phillips curves, Phillips lines and the unemployment costs of overheating. IMF Working Paper, 17.

Cooley, T., LeRoy, S. (1985). Atheoretical macroeconometrics: A critique. Journal of Monetary Economics, 16 (3), 283-308.

Datta, K., Mukhopadhyay, C.K. (2011). Relationship between inflation and economic growth in Malaysia. International Conference on Economics and Finance Research IPEDR. Retrieved from http://www.ipedr.com/vol4/82-F10100.pdf.

Dayioğlu, T., Aydin, Y. (2020). Relationship between economic growth, unemployment and inflation and current account balance: Theory and case of Turkey. Intechopen, 1-16. Retrieved from https://www.intechopen.com/chapters/73251.

Department for International Development. (n.d.). OECD. Retrieved from https://www.oecd.org/ derec/unitedkingdom/40700982.pdf.

Dzambaska, E., Lozanoska, A. (2014). Economic growth and unemployment: An empirical analysis (a case study on the Republic of Macedonia). Economic Development / Ekonomiski Razvoj, 3, 153-169. Retrieved from https://www.ceeol.com/search/article-detail?id=59654.

Erbaykal, E., Okuyan, H. A. (2008). Does Inflation Depress Economic Growth? Evidence from Turkey. International Research Journal of Finance and Economics, 17, 40-48. Retrieved from https://www.researchgate.net/publication/228206716_Does_Inflation_Depress_Economic_ Growth_Evidence_from_Turkey.

Eroğlu, Ö. (2004). A note on Phillips curve. Dergipark, 9 (1), 63-75.

Fisher, S. (1993). The role of macroeconomic factors on growth. NBER working paper, 4565.

Furuoka, F. (2007). Does the "Phillips curve" really exist? New empirical evidence from Malaysia. Economics Bulletin, 5 (16), 1-14. Retrieved from http://economicsbulletin.vanderbilt. edu/2007/volume5/EB-07E20006A.pdf.

Furuoka, F. (2008). Unemployment and inflation in the Philippines: New evidence from vector error correction model. Philippine Journal of Development, 25 (1), 93-106. Retrieved from https:// dirp4.pids.gov.ph/ris/pjd/pidspjd08-lunemployment.pdf.

Gillman, M., Harris, M., Matyas, L. (2004). Inflation and growth: Explaining a negative effect. Empirical Economics, 29, 149-167.

Great Britain DFID. (2008). Growth: Building Jobs and Prosperity in Developing Countries. London: Department for International Development. Retrieved from https://www.oecd.org/derec/ unitedkingdom/40700982.pdf.

Hsing, Y. (1989). On the relationship between inflation and unemployment: New evidence from six industrialized nations. Journal of Post Keynesian Economics, 12 (1), 98-108.

Israel, K.F. (2015). Reconsidering the long-run relationship between inflation and unemployment. Austrian Student Conference, 1-31. Retrieved from http://austrianstudentconference.com/ wp-content/uploads/2016/01/ASSC-2015-Israel-Karl-Friedrich.pdf.

Kigume, R.W. (2011). The relationship between inflation and economic growth in Kenya, 19632003. Doctoral dissertation, Kenyatta University. Retrieved from https://ir-library.ku.ac.ke/ handle/123456789/2124.

Kogid, M., Asid, R., Mulok, D., Lily, J., Loganathan, N. (2011). Inflation-unemployment trade-off relationship in Malaysia. Asian Journal of Business and Management Sciences, 1 (1), 100-108. Retrieved from https://www.researchgate.net/publication/230825236.

Kreishan, F. (2011). Economic growth and unemployment: An empirical analysis. Journal of Social Science, 7 (2), 228-231.

Lee, J. (2017). The labor market in South Korea, 2000-2016. IZA World of Labor, 405. DOI:10.15185/ izawol.405.

Lin, S.C., Huang, H.C. (2008). Smooth-time-varying Okun's coefficients. Economic Modelling, 25, 363-375. Retrieved from https://www.sciencedirect.com/science/article/pii/ S0264999307000892?via\%3Dihub.

Ekonomia - Wroclaw Economic Review 27/2 (2021)

(C) for this edition by CNS 
Mahmood, Y., Bokhari, R., Aslam, M. (2013). Trade-off between inflation, interest and unemployment rate of Pakistan: A cointegration analysis. Pakistan Journal of Commerce and Social Sciences, 7 (3), 482-492. Retrieved from http://www.jespk.net/publications/140.pdf.

Marinkov, M., Geldenhuys, J.P. (2007). Cyclical unemployment and cyclical output: An estimation of Okun's coefficient for South Africa. South African Journal of Economics, 75 (3), $373-$ 390. Retrieved from https://onlinelibrary.wiley.com/doi/abs/10.1111/j.1813-6982.2007.00134.x.

Mohsenia, M., Jouzaryan, F. (2016). Examining the effects of inflation and unemployment on economic growth in Iran (1996-2012). Procedia Economics and Finance, 36, 381-389.

Mubarik, Y. (2005). Inflation and growth: An estimate of the treshold level of inflation in Pakistan. SBP - Research Bulletin, 1 (1), 35-43.

Munir, Q. (2009). Inflation and economic growth in Malaysia: A threshold regression approach. ASEAN Economic Bulletin, 26 (2), 180-193.

Nell, K.S. (2000). Is low inflation a precondition for faster growth? The case of South Africa. Studies in Economics, 11. Retrieved from https://www.kent.ac.uk/economics/repec/0011.pdf.

N'Guessan, C.F. (2018). Nonlinear equulibrium relationship between inflation and unemployment: Evidence from Cote d'Ivoire. Journal of Business, Economics and Finance, 7, 76-82.

Okafor, I.G., Chijindu, E.H., Ugochukwu, U.S. (2016). Responsiveness of unemployment to inflation: Empirical evidence from Nigeria. International Journal of Scientific Research in Science, 2 (4), 173-179. Retrieved from https://www.researchgate.net/publication/311349523_Responsiveness_of_Unemployment_to_Inflation_Empirical_Evidence_from_Nigeria.

Ortansa, F. (2014). Relationship between inflation and unemployment in Romania, age group 20-24 years. Pratical Application of Science, 3, 198-203.

Özdemir, A., Mercan, M., Erol, H. (2012). Econometric analyses of the relations between defined macroeconomic variables in the labor market of Turkey. TISK Academy, 34-54.

Park, Y.C. (2005). A tale of two crises: Korea's experience with external debt management 1979-80 and 1997-98. Graduate School of International Studies, 1-46.

Phiri, A. (2014). Nonlinear co-integration between unemployment and economic growth in South Africa. Managing Global Transitions, 12 (4), 303-324. Retrieved from: https://www.fm-kp. si/zalozba/ISSN/1581-6311/12_303-324.pdf.

Powell, A. (1973). Consequences of unemployment. In A. Powell, Tempory Kings (50-69). London: Heinemann. Retrieved from www.aphref.aph.gov.au_house_committee_ewr_owk_report_chapter2\%20(1).pdf.

Prachowny, M.F. (1993). Okun's law: Theoretical foundations and revised estimates. The Review of Economics and Statistics, 331-336.

Rogoff, K. (2003). Deflation: Determinants, Risk, and Policy Options - Findings of an Inderdepartmental Task Force. Washington, D.C.: International Monetary Fund.

Ruxandra, P. (2015). The specifics of Okun's law in the Romanian economy between 2007 and 2013. Academica Brancusi, 2 (1), 50-53. Retrieved from https://www.utgjiu.ro/revista/ec/pdf/201501.Volumul\%202/07_Pitorac.pdf.

Sa'idu, B.M., Muhammad, A.A. (2015). Do unemployment and inflation substantially affect economic growth? Journal of Economics and Development Studies, 3 (2), 132-139. DOI:10.15640/ jeds.v3n2a13.

Senturk, M., Akbas, E. (2014). Econometric analysis of causal relationship between economic growth, inflation and unemployment: Case of Turkey. Journal of Yasar University, 5820-5832.

Seo, S.H. (2019). Low fertility trend in the Republic of Korea and the problems of its family and demographic policy implementation. Population and Economics, 29-35.

Sims, C.A. (1980). Macroeconomics and reality. The Econometric Society, 1-48.

Skare, M., Caporale, M. (2014). Short- and long-run linkages between employment growth, inflation and output growth: Evidence from a large panel. Technological and Economic Development of Economy, 554-575. 
Snyder, S.A. (2018). South Korea at the Crossroads: Autonomy and Alliance in an Era of Rival Powers. New York: Columbia University Press.

Soylu, O.B., Cakmak, I., Okur, F. (2018). Economic growth and unemployment issue: panel data analysis in Eastern European countries. Journal of International Studies, 93-107.

Ştefan, C., Bratu, A. (2016). The inflation-unemployment tradeoff in a macroeconometric model. British Journal of Economics, Finance and Management Sciences, 12 (1), 22-31. Retrieved from http://www.ajournal.co.uk/EFpdfs/EFvolume12(1)/EFVol.12\%20(1)\%20Article\%203.pdf.

Tari, R. (2014). Econometric Analysis. Kocaeli: Umuttepe Publishing House.

Tari, R., Koc, S., Abasiz, T. (2019). Econometrics. Kocaeli: Umuttepe.

Tenzin, U. (2019). The nexus among economic growth, inflation and unemployment in Bhutan. South Asia Economic Journal, 94-105.

Touny, M.A. (2013). Investigate the long-run trade-off between inflation and unemployment in Egypt. International Journal of Economics and Finance, 5 (7), 115-125. DOI: https://doi. org/10.5539/ijef.v5n7p115.

UKEssays (2018). The Korean Consumption Behavior. Retrieved from https://www.ukessays.com/ essays/cultural-studies/the-korean-consumption-behavior-cultural-studies-essay.php?vref $=1$.

U1-Haq, I., Khan, S., Khan, A., Ahmed, E. (2012). Phillips curve or locus critique: Time series evidence from Pakistan. Journal of Economics and Behavioral Studies, 4 (4), 190-193. Retrieved from https://www.researchgate.net/publication/299613550_Phillips_Curve_or_Locus_Critique_Time_Series_Evidence_from_Pakistan.

Umaru, A., Zubairu, A. (2012). An empirical analysis of the relationship between unemployment and inflation in Nigeria. Economics and Finance Review, 1 (12), 41-61.

Vaona, A., Schiavo, S. (2007). Nonparametric and semiparametric evidence On the long-run effects of inflation on growth. Economics Letters, 452-458.

Worldbank (2020A). Inflation, consumer prices (annual \%). Date of access: 18.12.2020, https://data. worldbank.org/indicator/FP.CPI.TOTL.ZG.

Worldbank (2020B). GDP growth (annual \%). Date of access: 18.12.2020, https://data.worldbank. org/indicator/NY.GDP.MKTP.KD.ZG.

Zaman, K., Khan, M.M., Ahmad, M., Ikram, W. (2011). Inflation, unemployment and the NAIRU in Pakistan (1975-2009). International Journal of Economics and Finance, 3 (1), 245-254. DOI: $10.5539 /$ ijef.v3n1p245.

Ekonomia - Wroclaw Economic Review 27/2 (2021)

(C) for this edition by CNS 


\section{Appendix}

Table 1A. Phillips-Perron unit root test

\begin{tabular}{|l|c|c|}
\hline \multicolumn{1}{|c|}{ Variables } & Intercept & Trend and Intercept \\
\hline GDP I $(0)$ & 0.9991 & 0.4125 \\
\hline GDP I $(1)$ & $0.001 * * *$ & $0.001 * * *$ \\
\hline INFLATION I(0) & 0.8055 & 0.8190 \\
\hline INFLATION I(1) & $0.0005^{* * *}$ & $0.0031^{* * *}$ \\
\hline UNEMPLOYMENT I $(0)$ & 0.0444 & 0.1858 \\
\hline UNEMPLOYMENT I $(1)$ & $0.0000^{* * *}$ & $0.0000^{* * *}$ \\
\hline
\end{tabular}

Note: $* \mathrm{p}<0.1, * * \mathrm{p}<0.05, * * * \mathrm{p}<0.01$

Null hypothesis: GDP, inflation, unemployment have a unit root

Source: Author.

Table 2A. VAR lag order selection criteria

\begin{tabular}{|c|c|c|c|c|c|c|}
\hline Lag & LogL & LR & FPE & AIC & SC & HQ \\
\hline 0 & -1150.658 & NA & $8.57 \mathrm{e}+24$ & 65.92332 & 66.05664 & 65.96934 \\
\hline 1 & -1000.294 & 266.3586 & $2.67 \mathrm{e}+21$ & 57.84540 & $\mathbf{5 8 . 3 7 8 6 6} *$ & 58.02948 \\
\hline 2 & -985.9231 & $\mathbf{2 2 . 9 9 4 0 8 *}$ & $\mathbf{1 . 9 9 e}+\mathbf{2 1} *$ & $\mathbf{5 7 . 5 3 8 4 6} *$ & 58.47167 & $\mathbf{5 7 . 8 6 0 6 1 *}$ \\
\hline 3 & -978.8957 & 10.03911 & $2.30 \mathrm{e}+21$ & 57.65119 & 58.98434 & 58.11139 \\
\hline 4 & -974.4988 & 5.527548 & $3.18 \mathrm{e}+21$ & 57.91422 & 59.64732 & 58.51249 \\
\hline 5 & -971.6313 & 3.113371 & $5.03 \mathrm{e}+21$ & 58.26464 & 60.39769 & 59.00097 \\
\hline
\end{tabular}

Note: Endogenous variables: GDP CONSUMER_PRICE_INDEX UNEMPLOYMENT

Exogenous variables: $\mathrm{C}$

* indicates lag order selected by the criterion

Source: Author.

Table 3A. Roots of characteristic polynomial

\begin{tabular}{|c|c|}
\hline Root & Modulus \\
\hline 0.966518 & 0.966518 \\
\hline $0.687878-0.302327 \mathrm{i}$ & 0.751384 \\
\hline $0.687878+0.302327 \mathrm{i}$ & 0.751384 \\
\hline $0.173314-0.679572 \mathrm{i}$ & 0.701324 \\
\hline $0.173314+0.679572 \mathrm{i}$ & 0.701324 \\
\hline 0.275465 & 0.275465 \\
\hline
\end{tabular}

Note: Endogenous variables: LNGDP LNINF UNEMP

Exogenous variables: $\mathrm{C}$

Source: Author.

Ekonomia - Wroclaw Economic Review 27/2 (2021)

(C) for this edition by CNS 
Ekonomia - Wroclaw Economic Review 27/2 (2021) (C) for this edition by CNS 